\section{札幌・福井における冬季入浴時 の室温変化に伴なう高齢者の血 圧変化の実態調查}

\title{
BLOOD PRESSURE CHANGE OF ELDERLY WITH ROOM AIR TEMPERATURE CHANGE DURING THE BATHING IN WINTER OF SAPPORO AND FUKUI
}

$\begin{array}{ll}\text { 斉藤雅也— } * 1 & \text { 羽山広文— } * 2 \\ \text { 坂倉恵美子— } * 3 & \text { 釜澤由紀— } * 4 \\ \text { 斉藤みゆき— } * 5 & \text { 進藤ゆかり— } * 6 \\ \text { 原井美佳—— } * 6 & \text { 斉藤美佳—— }\end{array}$

$\begin{array}{ll}\text { Masaya SAITO } & * 1 \\ \text { Emiko SAKAKURA } & * 3 \\ \text { Miyuki SAITO } & * 5 \\ \text { Mika HARAI } & * 6\end{array}$

Hirofumi HAYAMA - $* 2$
Yuki KAMAZAWA- $* 4$
Yukari SHINDO- $* 6$
Mika SAITO- $* 7$

キーワード

温熱環境, 高齢者, 入浴, 血圧, 寒冷地

Keywords:

Thermal environment, Elderly, Bathing, Blood pressure, Cold region

A field measurements of the blood pressure change of elderly with the room air temperature change during the bathing were made in winter of Sapporo and Fukui. Average room air temperatures of the undressing room in Sapporo versus Fukui were 19.8 versus 12.6 degree-C. The temperature differences between the living and the undressing room in Sapporo versus Fukui were 2.7 versus 6.5 degree-C, respectively. It would appear that the insulation performance of houses in Sapporo is higher that in Fukui. Therefore, over the 5 degree of air temperature drop between the living and the undressing room brings about a terrible rise in their blood pressure at the probability of 80 percent or more.

1. はじめに

人体周囲における急激な温熱環境の変化、いわゆる「ヒートショ ック」は、入浴時の裸体状態にあると、死亡事故に繋がる極めて危 険な温熱環境とされている。厚生労働省の人口動態統計データに基 づいて、住宅での心疾患・脳血管疾患の発生割合と住宅種別の関係 を分析した既往研究 1) 4) では、これらが冬季に集中し、高齢者の入 浴死と密接であることを明らかにしている。上記の疾患による浴室 での死亡事故の多くは、脱衣室や浴室の低断熱性に起因するとされ る。これまで、入浴時の人体の温熱生理・心理を実験的に明らかに 寸る研究 ${ }^{5)}$, 6) や、急激な温熱環境の変化に伴なう人体エクセルギー 消費の解析例 7) などいくつかの検討例はある。しかしながら、日常 の入浴時の温熱環境や生理データが実測されている例、特に死亡事 故が多発している寒冷地における高齢者を対象にしている例は極め て少ない ${ }^{8)}$ 。本研究では、寒冷地である札幌と福井に在住する高齢者 を対象にして、冬季の入浴時における室温変化に対する高齢者の血 圧変化を明らかする実測と解析を行なった。本報では、その結果と 考察を述べる。

\section{2. 実測概要}

表 1 に実測概要を示す。実測は 2009 年 12 月～2010 年 3 月にかけて、 札幌と福井に在住する、主として 65 歳以上の高齢者を対象に、事前 に研究の目的・内容を説明し、研究協力への同意が得られた 17 人（札 幌 9 人、福井 8 人）を被験者とした注）。実測は同意書を取得した後、 被験者の自宅に、温湿度計・血圧計・その他、データ記録紙などを 小包で送付し、終了後に小包を戻してもらう依頼形式とした。
2 台の温湿度計を自宅居間と脱衣室に設置し、被験者は入浴前の 居間（以降、「入浴前・居間」）にて室温を確認後、血圧・心拍数を 計測し記録する。次に、脱衣室に移動・脱衣後（以降、「入浴前・脱 衣室」）に、居間と同様に室温、血圧と心拍数をそれぞれ記録しても らった。入浴前に湯温を計測、記録してもらい、入浴後の居間（以降、 「入浴後・居間」）にて、同様に室温と血圧・心拍数を記録してもらった。 入浴時間は特に制限を設けなかった。以上を、入浴日について 5 回 分実施してもらい、札幌で 50 回分、福井で 40 回分のデータを得た。

\section{表 1 実測概要}

\section{【実測期間】札幌：2009 年 12 月 18 日 2010 年 3 月 07 日 福井： 2010 年 02 月 28 日〜 2010 年 3 月 25 日} （同意書の取得後、郵送による依頼調査形式）

【被 験 者】札幌：すべて札幌市に在住 9 人（男 $6 \cdot$-女 3 ) 福井：福井市・越前市・鯖江市に在住 8 人（男 $5 \cdot$ 女 3 )

【平均年齢】札幌：69.0 歳、福井：63.5 歳

【実測方法】(1)「入浴前・居間」にてく室温・生理データ>の計測と記録。 脱衣室に移動、脱衣後、

(2)「入浴前・脱衣室」にてく室温・生理データ >の計測と記録。 <湯温 $>$ の計測と記録 浴室から出て着衣後、

(3)「入浴後・居間」にて<室温・生理データ>の計測と記録。 1 回の計測が終了。

【生理データ】血圧 (収縮期 /拡張期) - 心拍数 （手首式血圧計 1 台 $/$ : エーアンドディ製 UB-511）

【室温データ】 被験者宅の居間室温・脱衣室の室温 (デジタル温湿度計 2 台 $/$ 世帯 : DRETEC 製)

【湯温データ】湯温（湯温計 1 台 /世帯 : 佐藤計量器製作所製）

【基礎データ】被験者の住宅属性（住宅種別、築年数、改築歴ほか） 浴室配置を含む平面図（被験者による手描き） 日常の入浴時刻、週あたりの入浴回数、入浴の好み。 既往歴、健康に対する満足度（自己申告）ほか。

\footnotetext{
札幌市立大学デザイン学部・大学院デザイン研究科 准教授・博士（工学） （干 005-0864 札幌市南区芸術の森 1 丁目）

北海道大学大学院工学研究院 教授・博士 (工学)

札幌市立大学看護学部・大学院看護学研究科 教授・博士 (医学)

北海道大学大学院工学院 大学院生

福井県丹南健康福祉センター

札幌市立大学看護学部 助教・看護学修士

フリーランス 修士（工学）

Assoc. Prof., School of Design, Sapporo City Univ., Dr. Eng.

Prof., Faculty of Engineering, Hokkaido Univ,, Dr. Eng.

Prof., School of Nursing, Sapporo City Univ., Dr. Med. Science

Graduate Student, Graduate School of Eng., Hokkaido Univ.

Tannan Health and Welfare Center, Fukui Prefecture

Assistant Prof., School of Nursing, Sapporo City Univ., MSN.

Freelance, M. Eng.
} 


\section{3. 実測結果と考察}

\section{1 室温変化の札幌・福井の地域による比較}

気象庁のアメダス気象データより札幌と福井の外気温を取得し、 室温との関係をそれぞれみた。外気温は被験者の自宅所在地の観測 点データを用い、記入されている入浴時間の前後 20 分間を対象とし た。図 1 はその外気温と「入浴前・居間」の室温、図 2 は「入浴前・ 脱衣室」の室温との関係である。札幌は塗りつぶし、福井は白抜き 印で示している。札幌の外気温は $0^{\circ} \mathrm{C}$ 以下であるが、居間の室温は $20^{\circ} \mathrm{C}$ 以上、脱衣室は $15^{\circ} \mathrm{C}$ 以上である。一方、福井は外気温が $0 \sim 10$ ${ }^{\circ} \mathrm{C}$ で居間の室温は $15 \sim 20^{\circ} \mathrm{C}$ 、脱衣室は $5 \sim 15{ }^{\circ} \mathrm{C}$ 、外気温とほぼ 同程度の場合も見られる。

図 3 は、札幌と福井における居間と脱衣室の室温変化である。標 準偏差は、札幌では居間 $1.9^{\circ} \mathrm{C}$ 、脱衣室 $3.0^{\circ} \mathrm{C}$ 、福井では居間 $3.9^{\circ} \mathrm{C}$ 、

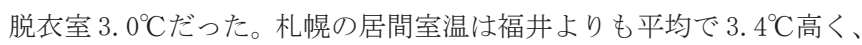
脱衣室の室温は福井よりも $7.2^{\circ} \mathrm{C}$ 高い。札幌では入浴時の居間から脱 衣室の室温は $2.7^{\circ} \mathrm{C}$ 低下寸るのに対して、福井では $6.5^{\circ} \mathrm{C}$ の低下があ る。したがって、札幌の住宅は福井よりも高断熱と考えられ、福井 では居住者（高齢者）が入浴する際の身体への熱的負荷が札幌より も大きいことが予想される。

図 4 は、「入浴前・脱衣室」の室温に対する湯温の関係である。脱 衣室の平均室温と湯温の強い相関は福井ではみられないが、札幌で はやや相関が見られ、室温が高いほど湯温が低い傾向がある。札幌 と福井の平均湯温を求めると、札幌は $40.1^{\circ} \mathrm{C}$ 、福井は $40.9^{\circ} \mathrm{C}$ である （標準偏差はともに 1.2）。この結果は、脱衣室の室温が低いと、湯温 を高めにする傾向があることを示唆している。

\section{3-2. 室温変化の住宅種別による比較}

表 2 は、基礎データに基づく被験者の住宅（札幌 SS1 〜 SS8、福 井FF1 ～FF7）の種別（戸建・集合）、築年数、浴室・脱衣室におけ る空の有無、浴室方位の一覧である。札幌はSS2、SS5、SS7 は戸建 住宅で、他は集合住宅、福井は寸べてが戸建住宅である。また、浴室・ 脱衣室の空の有無は、戸建住宅にはすべてに空があり、集合住宅（札 幌のみ）はすべてに空がない。

図 5 は「入浴前・居間」から「入浴前・脱衣室」の室温変化 (最大最小・ 標準偏差・平均）を住宅別に示したものである。図6は「入浴前・ 脱衣室」から「入浴後・居間」の室温変化を同様に示したものである。

図 5 で、試みに“室温変化がー $5{ }^{\circ} \mathrm{C}$ 以上の群”を A 群、“A 群以外の群” をB 群とすると、A 群は札幌の SS5 と SS7、福井の FF1、FF3 〜 FF7 で計 7 軒となる（FF3 は 5 回分の 3 回がー $5^{\circ} \mathrm{C}$ を回っていたので $\mathrm{A}$ 群とした)。一方、B 群は札幌の SS1 〜 SS4、SS6、SS8、福井の FF2、 FF8 で計 8 軒となる。図 6 にて室温変化が $+5^{\circ} \mathrm{C}$ 以上を A 群としても $\mathrm{A}$ 群と $\mathrm{B}$ 群は図 -5 と変わらない。

表 2 は札幌・福井の住宅の仕様で、種別の括弧内 $(3 / 6)$ は 6 階建 の 3 階を意味する。A 群にある札幌の SS5 と SS7 は、築年数が 35 〜 36 年の戸建住宅である。2 つの住宅が建てられた 1970 年代前半では、 住宅の断熱性に関する基準（呼称：「旧省エネルギー基準（1980 年 制定)」）が定められるよりも以前で、北海道においても当時の断熱 気密の施工技術では熱損失係数が $3.0 \mathrm{~W} /\left(\mathrm{m}^{2} \cdot \mathrm{K}\right)$ を上回る低断熱住

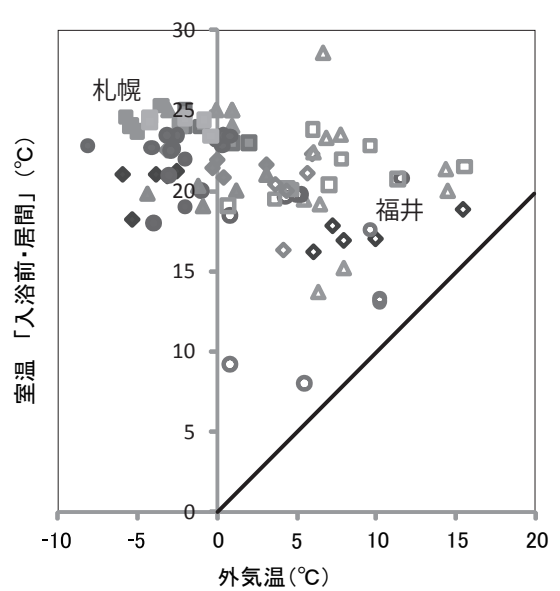

図 1 外気温と「入浴前・居間」の室温

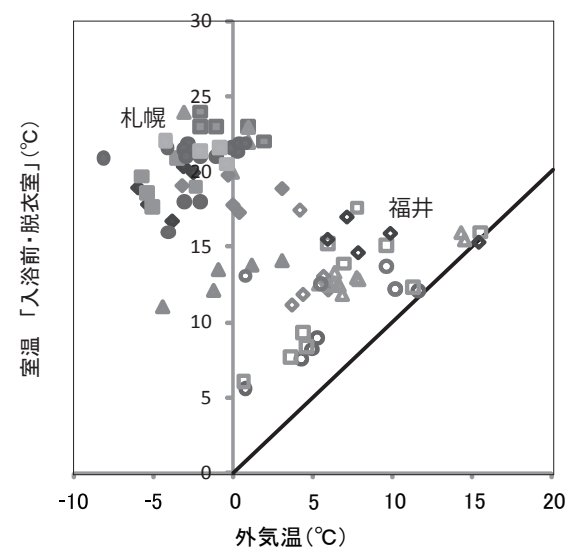

図 2 外気温と「入浴前・脱衣室」の室温

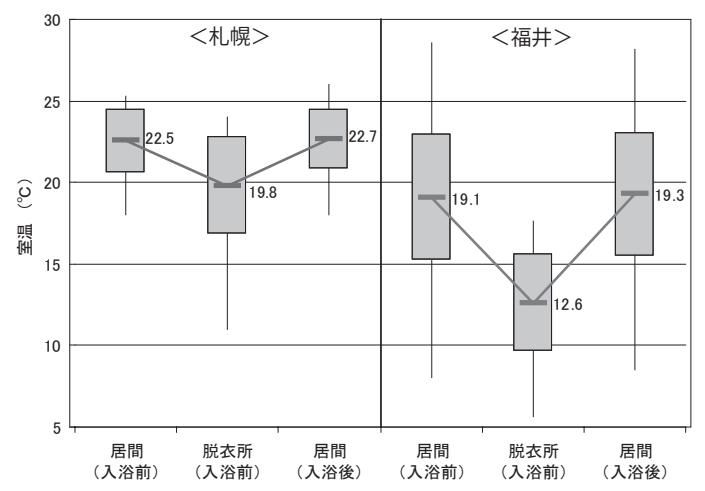

図 3 札幌と福井の居間と脱衣室の室温変化

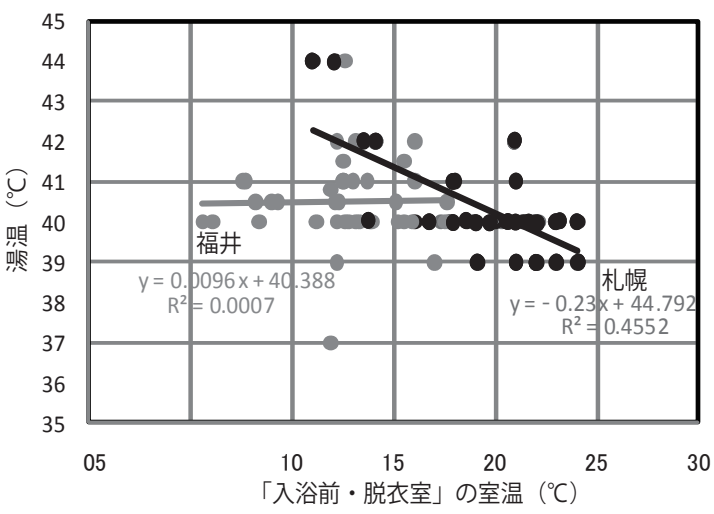

図 4 札幌と福井の脱衣室の室温に対する湯温 
表 2 札幌・福井の住宅データ

\begin{tabular}{|c|c|c|c|c|c|}
\hline & 番号 & 種別（階） & 築年数 & 空有無 & 浴室方位 \\
\hline 【札幌】 & $\begin{array}{l}\text { SS1 } \\
\text { SS2 } \\
\text { SS3 } \\
\text { SS4 } \\
\text { SS5 } \\
\text { SS6 } \\
\text { SS7 } \\
\text { SS8 } \\
\text { SS9 }\end{array}$ & $\begin{array}{l}\text { 集合 }(3 / 6) \\
\text { 戸建 } \\
\text { 集合 }(5 / 9) \\
\text { 集合 }(3 / 4) \\
\text { 戸建 } \\
\text { 集合 }(7 / 11) \\
\text { 戸建 } \\
\text { 集合 }(1 / 5) \\
\text { 集合 }(11 / 14)\end{array}$ & $\begin{array}{l}24 \\
21 \\
23 \\
25 \\
36 \\
28 \\
35 \\
21 \\
12\end{array}$ & $\begin{array}{l}\text { なし } \\
\text { あり } \\
\text { なし } \\
\text { なし } \\
\text { あり } \\
\text { なし } \\
\text { あり } \\
\text { なし } \\
\text { なし }\end{array}$ & $\begin{array}{c}\text { 東 } \\
\text { 西: 北 } \\
\text { 東 } \\
\text { 北 } \\
\text { 西 } \\
\text { 北 } \\
\text { 北 } \\
\text { 北 } \\
\text { 東 }\end{array}$ \\
\hline 【福井】 & $\begin{array}{l}\text { FF1 } \\
\text { FF2 } \\
\text { FF3 } \\
\text { FF4 } \\
\text { FF5 } \\
\text { FF6 } \\
\text { FF7 } \\
\text { FF8 }\end{array}$ & $\begin{array}{l}\text { 戸建 } \\
\text { 戸建 } \\
\text { 戸建 } \\
\text { 戸建 } \\
\text { 戸建 } \\
\text { 戸建 } \\
\text { 戸建 } \\
\text { 戸建 }\end{array}$ & $\begin{array}{c}12 \\
5 \\
16 \\
10 \\
10 \\
50 \\
12 \\
40\end{array}$ & $\begin{array}{l}\text { あり } \\
\text { あり } \\
\text { あり } \\
\text { あり } \\
\text { あり } \\
\text { あり } \\
\text { あり } \\
\text { あり }\end{array}$ & $\begin{array}{l}\text { 西 } \\
\text { 北 } \\
\text { 南 } \\
\text { 北 } \\
\text { 北 } \\
\text { 北 } \\
\text { 南 } \\
\text { 西 }\end{array}$ \\
\hline
\end{tabular}

宅であることが予想される。また、同じくA 群に属する福井の 5 軒 は、築年数は札幌よりも浅いが、戸建住宅で浴室・脱衣室に空があり、 居間よりも $5^{\circ} \mathrm{C}$ 以低い結果になっていると考えられ、脱衣室の低断 熱性が懸念される住宅と考えられる。

B 群に属する札幌の住宅はほとんどが集合住宅（ほとんどは分譲型 マンション）である。築年数が 20 年を超える住宅が多いが、当時の ほとんどの分譲型マンションにおける浴室の配置は外壁に面さない (窓がない) 型である。B 群では唯一の戸建住宅 SS2 は築年数が 21 年 で、1992 年に制定された「新省エネルギー基準」の 2 年前で、A 群 に属する SS5・SS7 よりも断熱性が優れていると考えられる。一方、 $\mathrm{B}$ 群の福井の FF2 は、築年数 5 年で最近の「次世代省エネルギー基準」 が反映された断熱性の良い住宅と考えられる。

図 5 の結果で、居間よりも脱衣室の室温が高い FF8 は、居間室温 が $10^{\circ} \mathrm{C}$ 以下で、脱衣室が $13^{\circ} \mathrm{C}$ (おそらく暖房をしているか、浴室か らの排熱が脱衣室に回っている）であった。そのため、計算結果が プラスとなる。FF 8 の温熱環境は高齢な居住者にとっては極めて㛜 しいものと考えられ、計算上は B 群であるが実質、低断熱な A 群に 属する住宅といえる。

\section{3-3. 室温変化に対する血圧変化}

図 7 は、「入浴前・居間」から「入浴前・脱衣室」への移動の際に 生じた室温変化に対する被験者の収縮期血圧の変化を、札幌と福井 に分けたものである。横軸は室温、縦軸は収縮期血圧の変化（いず れも「入浴前・脱衣室」と「入浴前・居間」の差）である。

被験者の血圧は、室温変化に伴ない上昇する（第 4 象限のプロッ トが多い)。室温が $10^{\circ} \mathrm{C}$ 以上低下寸る例が多い福井の血圧上昇は札幌 よりも顕著に大きく、両者の差は 40 〜 $60 \mathrm{mmHg}$ になる。室温低下と 血圧上昇の相関は福井でやや高く $\left(\mathrm{R}^{2}=0.18\right) 、$ 札幌ではみられない $\left(\mathrm{R}^{2}=0.02\right)$ 。血圧上昇は、居間から脱衣室への歩行移動と脱衣による 運動負荷の影響も含まれると考えられる。移動距離の影響について は今後の検討課題とするが、脱衣による運動負荷が被験者で同じと すると、福井の被験者の血圧低下は、居間から脱衣室の室温低下の 影響が大きく、住宅の低断熱性に起因するものと考えられる。

図 8 は、「入浴後・脱衣室」から「入浴後・居間」までの室温と

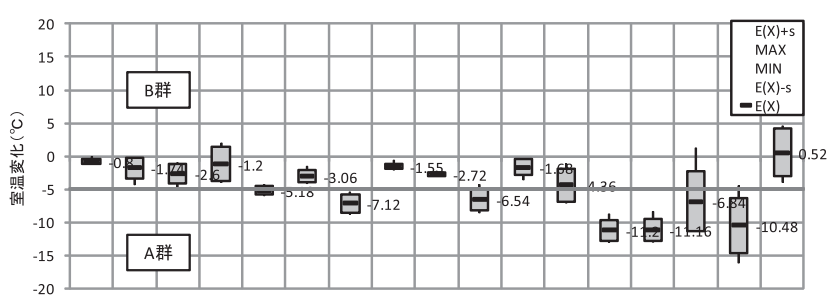

$\begin{array}{lllllllllllllllll}\text { SS1 } & \text { SS2 } & \text { SS3 } & \text { SS4 } & \text { SS5 } & \text { SS6 } & \text { SS7 } & \text { SS8 } & \text { SS9 } & \text { FF1 } & \text { FF2 } & \text { FF3 } & \text { FF4 } & \text { FF5 } & \text { FF6 } & \text { FF7 } & \text { FF8 }\end{array}$

図 5 住宅別の室温変化「入浴前・居間」 $\rightarrow$ 「入浴前・脱衣室

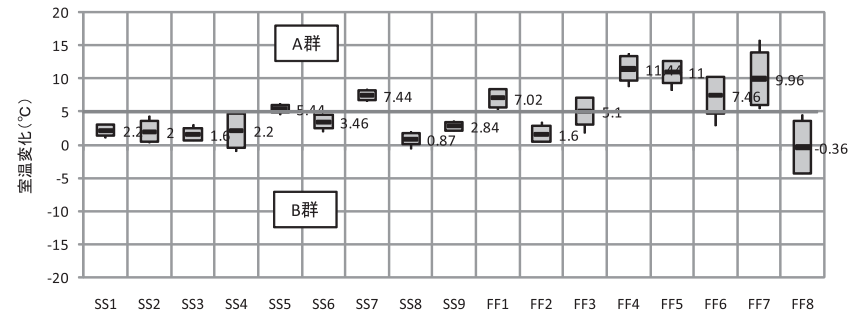

図 6 住宅別の室温変化「入浴前・脱衣室」 $\rightarrow 「 入$ 浴後・居間」

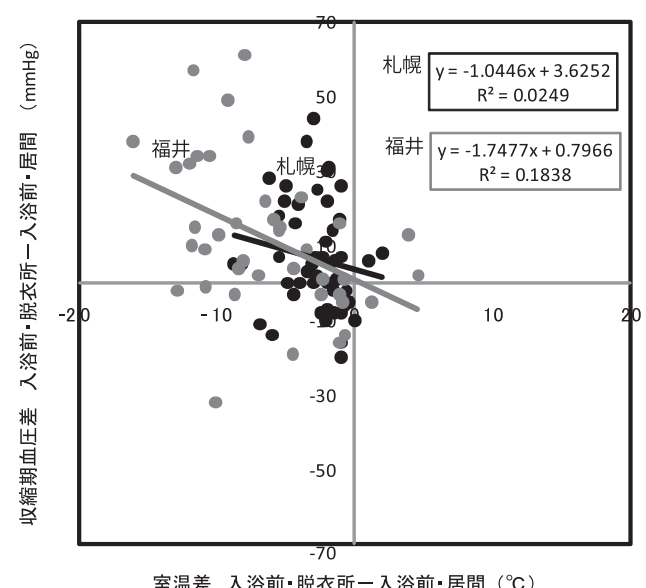

図 7 室温変化に対する収縮期血圧の変化 「入浴前・居間」 $\rightarrow$ 「入浴前・脱衣室

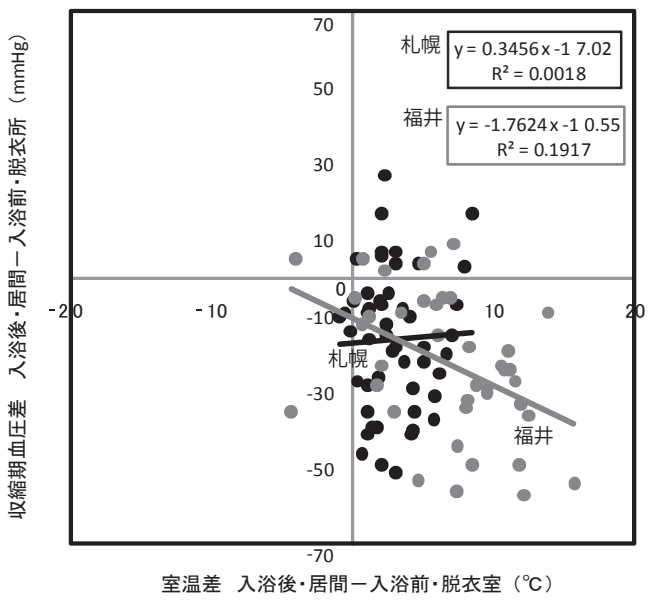

図 8 室温変化に対する収縮期血圧の変化 $\lceil$ 入浴前・脱衣室 $\rightarrow$ 「入浴後・居間 


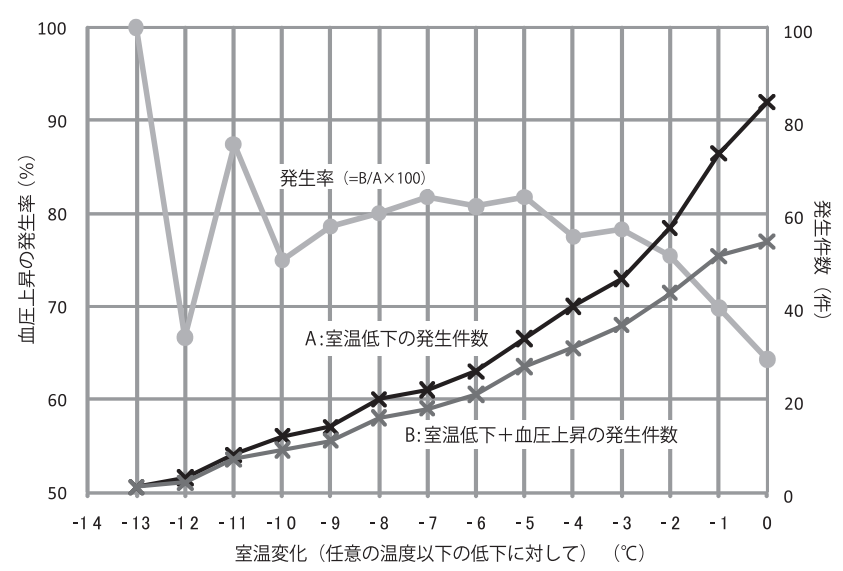

図 9 室温低下に対する血圧上昇の発生率

収縮期血圧の変化である。札幌、福井ともに入浴後は収縮期血圧は 下降する（第 2 象限のプロットが多い）。これは $40^{\circ} \mathrm{C}$ 前後のお湯に 身体が浸かった後、浴室から出て、服を着て暖房された居間に戻る 一連の過程による血圧降下と考えられる。図 7 と同様に、福井の方 が室温上昇と血圧降下の相関が高く $(R 2=0.19)$ 、札幌では相関がな い( 0.00$)$ 。札幌と福井の外気温の差と人体周囲空気の温度变化が血 圧に与える影響は、血圧と心拍数の二重積 ${ }^{8}, 9$ 、人体のエクセルギ 一消費速度 7) を明らかにするなどの数值解析が必要と考えられるが、 今後の課題としたい。

図 9 は、入浴前の居間から脱衣室の室温低下に対する血圧上昇の 発生率である。発生率は「室温低下十血圧上昇の発生件数」は「室 温低下の発生件数」で除して 100 倍した值である。ほとんどの被験 者は高齢者だが、既往症の有無などの個人差が大きく、血圧の絶対 值を比較することは困難と考え、室温低下に対する血圧上昇の件数

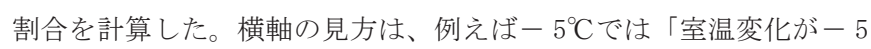
${ }^{\circ} \mathrm{C}$ 以下の場合」を意味する。発生率が $80 \%$ を超える点は、室温変化 がー $4^{\circ} \mathrm{C}$ から $-5^{\circ} \mathrm{C}$ の間で、これは前述の $\mathrm{A}$ 群と B 群に分けた住宅種 別の境界にあたる。居間から脱衣室への室温低下が $5{ }^{\circ} \mathrm{C}$ 以上（低断熱 住宅 : A 群）になると、 $80 \%$ の確率で血圧が上昇すると言える。

図 10 は、同様にして入浴後の室温上昇に対する血圧下降の発生 率を示したものである。「入浴前・脱衣室」と「入浴後・居間」の間 に入浴があるので、被験者の血圧はほとんどの場合で下降する。

\section{4.まとめ}

札幌と福井の高齢者の冬季入浴時の室温変化に対する血圧変化の 実測と解析から以下が確認できた。

1 ）札幌は居間 $22.5^{\circ} \mathrm{C}$ 、脱衣室 $19.8^{\circ} \mathrm{C}$ の室温に対して、福井は居間 $19.1^{\circ} \mathrm{C}$ 、脱衣室 $12.6^{\circ} \mathrm{C}$ である。福井は札幌よりも外気温が $10^{\circ} \mathrm{C}$ 程度高いのだが、住宅内の温熱環境は札幌より居間で $3{ }^{\circ} \mathrm{C} 、$ 脱 衣室で $7^{\circ} \mathrm{C}$ 低い寒泠環境である。平均湯温は札幌 $40.1^{\circ} \mathrm{C}$ 、福井 $40.9^{\circ} \mathrm{C}$ で、脱衣室の室温が低い寒冷環境では、湯温をやや高め にする傾向がある。

2 ）居間と脱衣室の室温変化が小さいのは、札幌の集合、札幌・福 井とも築年数の浅い戸建である。一方、室温変化が大きいのは、 札幌では築年数 35 年以上、福井では 10 年以上の戸建住宅である。

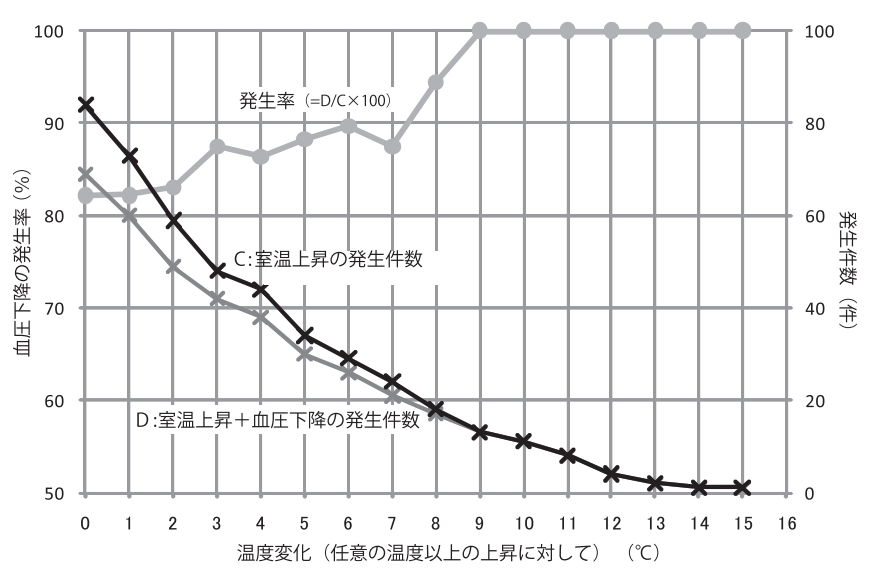

図 10 室温上昇に対する血圧下降の発生率

3 ）居間から脱衣室への室温低下に対する血圧上昇の相関は、福井 の方が札幌よりも顕著である。室温の低下が $5{ }^{\circ} \mathrm{C}$ 以上になると、 80\%の確率で血圧が上昇すると考えられる。

\section{謝辞}

本研究を実施するにあたり、札幌と福井の 17 世帯の被験者の皆さ ま、福井のお風呂と健康を考える会「お風呂ネットふくい」の皆さま、 福井県介護実習・普及センターの金牧裕美様には多大なご協力とご 支援をいただいきました。ここに記して謝辞とします。

注

本研究は、2009 年度 公立大学法人札幌市立大学倫理委員会に対して、研究 課題「室内の温熱環境が高齢者の身体へ与える影響の実態把握に関する研究 (研 究代表 : 斉藤雅也)」の倫理申請を行ない、審査・承認された内容について実 施したものである。なお、本研究は、2009～2010 年度日本建築学会北海道支 部特定課題研究委員会「住環境の変化が身体へ与える影響の実態把握（主査： 羽山広文)」の支援を受けている。

\section{参考文献}

1) 羽山広文・松村亮典・絵内正道・菊田弘輝・森太郎：建築都市の安全性の評 価分析とバリアフリー対策 その 1 人口動態統計データを用いた疾病発生の 分析、日本建築学会大会学術講演梗概集 (D-2)、pp. 427-428、2007.8。

2) 松村亮典・羽山広文 $\cdot$ 絵内正道・菊田弘輝・森太郎 : 建築都市の安全性の評 価分析とバリアフリー対策 その 2 入浴時の浴室温熱環境調査、日本建築学 会大会学術講演梗概集 (D-2)、pp. 429-430、2007.8。

3) 羽山広文・釜澤由紀 : 住環境が死亡原因に与える影響 その 1 気象条件・死 亡場所と死亡率の関係、日本公衆衛生学会総会、00803-12、2009.10。

4）釜澤由紀・羽山広文・絵内正道・菊田弘輝・松村亮典：人口動態統計デー夕 を用いた都市における浴室内溺死・溺水に関する研究、空気調和・衛生工学 会大会学術講演論文集、pp. 1279-1282、2009.9。

5) 久保博子・磯田憲生・高田暁・永井廉子 : 入浴行動と入浴時の温熱環境の実 測調查、日本建築学会大会学術講演梗概集 (D-2)、pp. 479-480、2003.9。

6) 津本美和・ 久保博子・磯田憲生・八木廉子 : 入浴行動と入浴時の温熱環境の 実測調査 : 夏期と冬期における通常入浴時の温熱環境と生理・心理反応につ いて、日本建築学会大会学術講演梗概集 (D-2)、pp. 521-522、2006.9。

7) 斎藤雅也・宿谷昌則 : 熱環境の変化が人体エクセルギー収支に及ぼす影響 に関寸る検討、日本建築学会北海道支部研究報告集 No. 74、pp. 163-166 2001.7。

8) 齐藤雅也 ・羽山広文 ・ 坂倉恵美子 ・ 進藤ゆかり ・原井美佳 ・ 釜澤由紀 ・ 香西 里美・村上智彦 : 寒冷地における高齢者の入浴前後の生理反応に関寸る実測、 空気調和・衛生工学会大会学術講演論文集、pp. 1275-1278、2009.9。

9）高橋龍太郎・小太刀一光・杉山智美・前川佳史 : ミストサウナを活用した高 齢者向け入浴方法の検討 その 2 入浴時の生理反応の変化、日本建築学会大 会学術講演梗概集 (D-2)、pp. 419-420、2007.9。 